\title{
Introduction: Going Public
}

\author{
PAUL ASHTON
}

$\mathrm{T}$ This volume of Public History Review presents six of the papers delivered at an international colloquia convened at the University of Technology, Sydney in September 2010 entitled 'New Directions in Public History'. (Other papers from the colloquia will be published in a future volume of Public History Review. $)^{1}$ The colloquia addressed in part the ways in which public historians have recently responded to challenges and opportunities thrown up by, among other things, shifting cultural authority, changing political environments, social movements and globalisation in a digital age. In doing so, it also highlighted tensions in the ways in which public history has been defined and perceived over time.

Public history is an elastic, nuanced and contentious term. ${ }^{2}$ Its meaning has changed over time and across cultures in different local, 
regional, national and international contexts. In the United States of America, where contemporary public history is most firmly established and widely practiced, the term is commonly attributed to Robert Kelley, an environmental historian then at the University of California, Santa Barbara, who is said to have coined it in 1975. 'Public history', Kelley wrote in the first issue of The Public Historianthe academic-styled journal of the National Council on Public History - referred 'to the employment of historians and historical method outside of academia'. ${ }^{3}$ The name, however, was not universally adopted. Some university departments preferred the label 'applied history', ${ }^{4}$ bestowing upon the fledgling field a blue-collar status which it subsequently endeavoured to shrug off. Applied history, which technically involved harnessing history to problems in public policy, was often used interchangeably with 'public history'. But many in the American academy had another preference which was to largely ignore what was to become at one level a sub-discipline of academic history.

Kelley's simple, pragmatic definition was adopted and refined by the 'public history movement', as professional practitioners broadly termed themselves. Ultimately, many in the movement conceded, as witnessed in the editorial policy of The Public Historian, that there was a 'considerable diversity of approaches to the definition and practice of public history'.$^{5}$ But as early as the 1980s two at times overlapping categories of 'public historian' had been delineated: the academically trained practitioner and the academic public history educator. (By the beginning of the twenty-first century there were more than 50 graduate public history programs in American Universities.)

Thus in 2003, while acknowledging the inter- and multidisciplinary nature of public history and trying to accommodate a range of professionals from disciplines such as archaeology, information knowledge management, museum studies, oral history and historical administration, David Vanderstel, Executive Director of the National Council on Public History, wrote that public historians were 'those [trained in but] engaged in work outside the halls of the academy and those within the academy who prepare students for careers in government agencies, museums, libraries, historic preservation, and in private business enterprises'. ${ }^{6}$ This definition neatly described the membership of the National Council on Public History, which since its establishment in 1980 has contributed greatly to enhancing history's place in both public and 
corporate culture in the United States. And it was reiterated in a special issue of The Public Historian in 2006 which addressed public history as reflective practice. ${ }^{7}$ But it excluded large numbers of Americans who were making histories or participating in historical pastimes in public spaces.

Roy Rosenzweig and David Thelen investigated these historical activities and the social needs and historical sensibilities underlying them in an extensive national survey. Amid history wars and in an increasingly politically conservative climate, The Presence of the Past: Popular Uses of History in American Life ${ }^{8}$ was important for a number of reasons. Firstly, it demonstrated the complex ways in which people used the past in making themselves and their lives, negotiated the present and navigated the future. The Presence of the Past also discredited conservative and elitist claims that there was a collective national history, essential to civic cooperation and advancement in difficult times, with which the general public was not well versed. Such sentiments were in part expressed in 1996 when academic historian, Professor Sheldon Hackney, former Chair of the National Endowment for the Humanities, announced that 'there is an inclusive historical narrative in which we all recognise not only the stories of our kith and kin but in which we acknowledge that we are playing roles in a common story'. ${ }^{9}$ At stake were social cohesion, the 'national character' and the authority of the professional historian. ${ }^{10}$ This leads us to the third reason for the project's importance: it reconfirmed that academic history was but one of a myriad of historical practices. As Thelen observed in his afterthoughts on the project, published online, their controversial book provided 'evidence that academic history differs from everyday history' ${ }^{11}$

Thelen, however, did not seek to set the academy against the rest. He acknowledges the longstanding gulf between academic historians and what some academics would see as their laity. ${ }^{12}$ So too does Patricia Mooney-Melvin who among others has traced over the late nineteenth and most of the twentieth century the growing insularity and disinterest of the professional historian vis-a-vis robust and rising communities of local and community historians and preservationists. ${ }^{13}$ And Thelen is critical of professionals who dismiss experience as inconsequential, private or self-deceptive ${ }^{14}$ or fail to respect 'differences in grandmothers' stories, museum exhibitions, and manuscript collections as trusted sources for approaching the 
past. ${ }^{15}$ But he argues for a participatory historical culture where the 'past should be treated as a shared human experience and opportunity for understanding, rather than a ground for division and suspicion'. ${ }^{16}$

Others share this view. David Glassberg, in his book Sense of History: The Place of the Past in American Life, has urged professional historians to reach in 'to discover the humanity they share' rather than positioning themselves as aloof, superior beings. ${ }^{17}$ Hilda Kean has also noted that personal need or attractions to various pasts are fundamental to coming to grips with variant understandings of history. ${ }^{18}$ Thelan too notes the artificiality of separating the public from the private. 'A fundamentally historical culture centred on individual participation', he reflected,

Would invite members to explore just how individuals conform to and resist larger historical trends, how the rhythms and narratives of family life fit or do not fit those of changing power and institutional arrangements in the larger society... It would take seriously how they live lives and meet needs in relationships driven by forces different from those that power institutions and cultures. ${ }^{19}$

Roy Rosenzweig's afterthoughs on The Presence of the Past came out of another critique of mainstream professional history. Some radical historians railed against the new professionals: public historians. Ronald Grele, a community and oral historian, asserted in an early volume of The Public Historian that public history was not de novo. It was

moving into fields long occupied by practising nonacademic historians... Because the public history movement has ignored these debates, it seems to have accepted a much narrower idea of the profession. ${ }^{20}$

For Grele, public history also held out the possibility of a participatory historical culture but one in which people had a firm hand in the making of their own pasts. In the same year, 1981, Howard Green - later to become President of the Oral History Association of America and Commissioner of the New Jersey Historical Commission - wrote in Radical History Review of the way in 
which non-academic historians in the community felt patronised by their supposed professional betters. ${ }^{21}$ Rosenzweig similarly argued two decades later that professional historians still needed 'to work harder at listening to and respecting the many ways popular historymakers traverse the terrain of the past that is so present for all of us'.$^{22}$ Unlike Thelen, Rosenzweig's underlying motivation was driven by a desire for social justice and support for social change movements that challenged conservative and traditional agendas. ${ }^{23}$ Grele, too, saw as a worst case senario professional historians pouring their 'energies into hucksterism for the status quo'. ${ }^{24}$

Another radical perspective on public history was to emerge in the United States. Perhaps its clearest expression is to be found in Radical History Review, a left-wing, scholarly journal established in the 1970s. Drawing on contributions to this journal, Susan Benson, Stephen Brier and Roy Rosenzweig edited a book published in 1986 which presented public history as politically interventionist, activist and community centered. ${ }^{25}$ In 1999, under the direction of Danny Walkowitz, a professor at New York University who ran a graduate program in public history, the journal launched, as a regular feature, a two-pronged series in public history aimed at broadening understandings of the field. The first examined how 'racial' others and imperial pasts played out in national histories. The second looked at the extent to which national narratives constructed by previous political regimes were questioned by public representations of the national story commissioned or endorsed by succeeding regimes. ${ }^{26}$ The series continues to date and has lead to two edited collections. ${ }^{27}$ This approach to public history focussed attention on the use and abuse of history by the state particularly in terms of collective memory at a national level. Ludmilla Jordanova has observed that 'the state... lies at the heart of public history' ${ }^{28}$ Jeremy Black, in his book, Using History, also examines 'the uses that are made of history in the public domain' by governments, ruling elites and societies. ${ }^{29}$

The term public history has only recently gained currency in Britain. Though Ruskin College, Oxford, has been conducting annual public history conferences since 2000, the first international public history conference in Britain - 'People and their Pasts' - was held there in 2005. One result of this was the publication of the edited collection People and Their Pasts: Public History Today. ${ }^{30}$ A conference 
conducted at York University in 2001 entitled 'Historians and their Publics' also in part addressed the field. Other public history-named events are now mushrooming and the term is being taken up in different contexts.

In Contested Pasts: the politics of memory, Katherine Hodgken and Susannah Radstone rightly contend that much work in the field of cultural and social memory has 'come to be known as "public history"' ${ }^{31}$ Public history and the study of memory overlap as both deal with collective memory as well as historical consciousness. ${ }^{32}$ David Glassberg, arguably, wrote the most seminal article on this topic in the United States. ${ }^{33}$ David Lowenthal, one of the numerous respondents to Glassberg's piece, wrote that 'individual life-histories uniquely illuminate historical sources and context'. ${ }^{34}$ Popular cultural forms such as film, re-enactments and museums, provinces too of the public historian, also contribute to shaping collective memory.

Public history's reception by the British academy has in general been more in accord with the North American Experience. An academic conference held at Trinity College, Cambridge, in 2001 to mark the fortieth anniversary of the University's Institute of Historical Research, had as its theme: 'What is history NOW?'. One of the contributors observed that much of the 'recent explosive growth in history... has been in popular taste and demand, to which professional historians have contributed little and responded hardly at all'. But ultimately academic historians were held up at this gathering as having 'a certain obligation of guidance, even of leadership'. ${ }^{35}$ Public history rated one specific though fleeting mention by Paul Cartledge who concurred with Ludmilla Jordanova on the 'necessity for historians to engage in and with what has been called, with some imprecision admittedly, "public history"'. ${ }^{36}$ Jordanova had recognised the complex nature of the label 'public history' in a stimulating, introductory chapter on the field published in 2000. And she immediately conceded that many of her readers were then 'likely to be unfamiliar with the phrase "public history"'. ${ }^{37}$ But history is clearly 'going public' in Britain today. ${ }^{38}$

Public history's relatively recent emergence in British historiography has generated debate. Some of this has centred on a distinction between the 'public' and the 'private' or personal. Academic Jill Liddington, in a broad ranging, exploratory article in the journal Oral History, suggested that '[s]ome public historians are surely just "private historians" in cunning disguise: may not writing 
a commissioned history for a private corporation be nearer "public relations" than "public history"'? ${ }^{39}$ This argument was put forward in the 1980s by David Cantor, an American historian of medicine, who erroneously contended that 'good history' was undermined by the 'purse-strings and obligations of contract work' ${ }^{40}$ Commissioned history, for Cantor, inevitably takes on the agenda of the commissioner. But critical distance affects all form of knowledge production. This does not exclude fields influenced by ideological fashions and funding regimes for academic work.

Most controversially, as she admits, Liddington questioned the public worth of genealogy, family and local history. Positing a binary and I would contend artificial divide, she asks: 'who are public historians: publically-funded, publically accountable academic historians or enthusiastic grassroots practitioners?' ${ }^{41}$ The answer was academic historians. Public historians, she concludes, 'provide refreshing, inspiring and necessary expert mediation between the past and its publics. ${ }^{\prime 2}$ Expert public historians, for Liddington, would 'maintain the highest standards of scholarship and critical rigour'. ${ }^{43}$ 'Purveyors of the past to popular audiences', she warned, would ignore these 'historians at their peril'. 'These' historians, however, are often overlooked by commercial history enterprises. Traditional historians are not known, to use Television parlance, for their 'talent'. ${ }^{44}$

Academic historians have a discourse to shore up their authority, destablised as this may be, which is in one sense unassailable. But some critical history, particularly that with a tendency to moralise or be didactic, has alienated some of traditional history's audiences in the new, postcolonial global environment. ${ }^{45}$ Now there are those who deem 'real' history to reside in academic institutions, where it occasionally works to enlighten lay practitioners, and those who see history as a 'public thing'. As Greg Denning has observed, for the latter, history

Didn't belong to academic history departments. It didn't belong to establishment antiquarians ... there were historians in museums, galleries, in archives, in newspapers, in schools whose needs were not being met by academic history departments. ${ }^{46}$ 
Others, such as Jordanova, have recognised that the 'past is essentially open-ended, and accounts of it are public property, available for numerous uses'. ${ }^{47}$

Raphael Samuel, who started the History Workshop movement in 1966 and who taught for 30 years at Ruskin College, Oxford - a labour movement college for adults ${ }^{48}$ pointed earlier to the importance of local historians and the diverse, non-traditional range of materials they drew upon to construct their pasts. ${ }^{49}$ Indeed, he returned

again and again to the idea of history as an organic form of knowledge, and one whose sources are promiscuous, drawing not only on real-life experience but also on memory and myth, fantasy and desire; not only on the chronological past of the documentary record but also the timeless one of tradition..$^{50}$

History was thus 'a social form of knowledge; the work in any given instance, of a thousand different hands. ${ }^{51}$ Growing out of socialism, the History Workshop movement spread to South Africa and Ireland and later influenced a number of public historians in Australia and New Zealand. It was concerned with facilitating democratic scholarship in part through the creation of hospitable, collaborative environments for all who had an interest in the past. This included local and community historians, curators, archaeologists, archivists and teachers. The movement promoted the history of everyday life. Its founder also rightly contended that the subject matter of history and the process of the production of history were inextricably connected. For Samuel, historical content was, as Kean observes, directly linked to the history maker. This was not a position he had recently adopted in Theatres of Memory; it had been at the core of his practice for three decades. ${ }^{52}$

Hilda Kean, Paul Martin and Sally Morgan similarly noted that public history involved the positive entanglement, rather than the separation, of the personal and the public as well as the utilization of fresh material. Public History, they contended

Acts as an umbrella, under which the historical mind can be brought to bear on areas of research and thought which are too often seen as mutually exclusive. It draws upon the magazine racks of W.H. Smith for source material as much 
as it draws on academic texts. It looks as much to images and textual conceptions on commercial packaging and television advertising as it does to the art gallery and museum. It seeks oral opinion conveyed through the domestic images recorded by camcorder, constructed images and visual texts on television, and the holistic nature of the idea of knowledge expressed by the internet. ${ }^{53}$

Such entanglements make for a good deal of grey areas; black and white definitions are difficult, indeed undesirable if they stifle creative practices and interventions. This was clear in the wide range of contributions in their collection which aimed to break down traditional boundaries and revisit 'ideas either relegated to academic practice or dismissed as the concern of enthusiastic amateurs' ${ }^{\prime 54}$

In Australia and New Zealand, with their respective populations of just over 22,500,000 and 4,300,000 - history has been forced out of its cloisters for around two decades. The New Zealand experience, similar to that of Australia, is outlined in Bronwyn Dalley and Jock Phillips edited collection, Going Public. Here, they define public history as 'historical work undertaken according to the research priorities, agendas or funding capacities of another party other than being self-directed by the Historian. Seen in this way', they note, 'public history occurs in museums, in government, sometimes in universities, and in the independent freelance community ${ }^{55}$ Graeme Davison, now Emeritus Professor of History at Monash University, has neatly described Australian public history as the 'practice of history by academically trained historians working for public agencies or as freelancers outside the universities'. ${ }^{56}$ Both definitions adopt, consciously or otherwise, the American 'public history movement's' conception of the field. But both definitions exclude a range of practitioners who undertake history with affect in various Australian public arenas. Davison, indeed, immediately goes on to note that while the north American term 'public history' was not adopted until the late 1980s in Australia, public historians could be traced back at least to C.E.W. Bean, who played a major role in shaping the national legend of Anzac from World War I and who was largely responsible for the establishment of the Australian War Memorial, a major museum and a national archives for war records. Bean, however, was not an academically trained historian. He 
studied law at Oxford University and subsequently became a journalist who turned his hand to writing nationalist history.

In citing Bean, Davison hints at tensions over the term 'public history'. I use the work tension since a debate in Australia has yet to be ignited. People in the field seem largely content to get on with their practice, leaving reflective work to a handful of individuals. ${ }^{57}$ Professional associations - which were formed in South Australia during 1981; Victoria in 1983 (as part of the History Institute of Victoria; self-determining from 1991); New South Wales, 1985; Western Australia, 1989; Queensland, 1990; Tasmania, 1992; and the Northern Territory in 2001 - generally limit their activities to workrelated matters and publications such as codes of ethics. The number of freelance historians in Australia today - around 350-400 outnumbers historians employed full-time in the academy.

Public history in Australia has been shaped by specific local conditions, which vary from state to state, region to region and place to place, and by largely British and American influences including Britain's people history movement and the less influential applied history model that emerged in the United States. The rise of graduate university programs in various states led by academics with different styles and ideological persuasions has also impacted significantly on public history. The first public or applied history courses offered at tertiary level were at the University of Technology, Sydney, and Monash University in $1988 .^{58}$ It has also been moulded by the active worlds of history that exists across the continent, from organised historical societies and family history groups, of which there are around 1000 in Australia today, to individual collectors of historical objects.

In his Use and Abuse of Australia History, Graeme Davison recollects that his engagement with public history evolved out of a hobby and a sense of 'professional obligation' to enthusiasts. 'Only gradually', he notes in the preface to this work, did he realize that 'everyday forms of history-making' were both transforming and challenging the academic discipline of history. ${ }^{59}$ Elsewhere, Davison has depicted public history as an expression of a desire to bridge a perceived gap between academic history and the Australian public. ${ }^{60}$ Others see this differently. For Raphael Samuel, history in the public arena is 'the ensemble of activities and practices in which ideas of history are embedded or a dialectic of past-present relations is rehearsed'. In this sense, public history is an engagement with such 
activities and practices. ${ }^{61}$ These can range from ceremonies and rituals of 'social integration' ${ }^{62}$ to public landscapes, monuments and memorials, museums and exhibitions, school texts and classrooms, historical films and novels, family stories, songs, memories and family and local history-making. Most of these activities do not involve academic or professionally trained historians. As Ashton and Hamilton have argued, in Australia 'for many future historians, the academy - offering training, pastoral care and some opportunities for employment - will be part of a network of organisations and institutions that sustain historical practice. ${ }^{\prime 3}$ That future has arrived. That the house of history has many rooms, only one of which accommodates academic historians, has emerged strongly in an Australia study, Australians and the Past, which is based on Rosenzweig and Thelen's The Presence of the Past. ${ }^{64}$

The period in which the public history movement has developed has been one of considerable change. This is not simply a result of the passing of post-war generations. It is also because of the effects wrought by continuing internal and external conflicts, the globalisation of economies, the emergence of new media forms and the major impact of the digital revolution. Significant shifts have occurred in the transmission, reception and practice of history.

There is an increasing passion with the past both personally and in a range of public arenas. A growing preoccupation with the past for the public consumption of history has been matched by a proliferation of sites - including memorials, museums, television, film and national parks - and practices - such as local history, family history, genealogy, autobiography and re-enactment - which are all now viewed as constituting our cultural memory and its social expression. A boom continues in the popularity of historical novels and biography. This increase in historical activities is not only about consumption; it relates to atomisation (increasingly on an individual level) and to people taking control of making and interpreting the past. While not necessarily changing all practices, new technologies have helped democratise the processes by making written, visual and audio records far more easily accessible and through the facilitation, for example, of on-line publications of work such as biography and autobiography. In this way, relationships between history and different types of media have become stronger. Media, too, has become even more central to shaping collective memory, 
loosening the hold of traditional, bookish history. These developments have also meant that the boundary between personal and public pasts are increasingly permeable.

Such significant change has also brought into question, if not undermined, the role of the academic historian. Both the many seen and unseen 'publics' - from museum visitors to virtual historical communities - and the concept of history itself, have ebbed and flowed so much so that the question of social and cultural authority has become a significant issue. We know now that, more and more everyday, new sources, ideas and forms of historical knowledge are being generated outside the academy. We also know that public historians, those who work in a professional capacity outside universities, do not just translate or popularise history for a lay public or mediate between institutions or different groups. They utilise their professional skills in a variety of ways to make important contributions to how we think about the past and its meaning. As Marnie Hughes-Warrington has noted, "there is no "history" apart from historical practices. Nor, in consequence, is there any logical, universal or unchanging reason to talk of one practice as "more historical" than another. If we value some historical practices over others, it is because of historical decisions. And because our views on what history is are themselves historical, they are subject to reevaluation and change. ${ }^{65}$

\section{ENDNOTES}

${ }^{1}$ I would like to thank Paula Hamilton for input into this article.

${ }^{2}$ See, for example, Hilda Kean and Paul Ashton, 'Introduction' in Paul Ashton and Hilda Kean (eds), People and Their Pasts: Public History Today, Palgrave Macmillan, Basingstoke, 2009, pp1-20.

${ }^{3}$ Robert Kelley, 'Public History: its origins, nature and prospects', The Public Historian, vol 1, no 1, 1978, p16.

${ }^{4}$ Constance B. Schulz, 'Becoming a Public Historian', in James B. Gardner and Peter S. LaPaglia (eds), Public History: Essays form the Field, Malabar, Krieger Publishing Company, Malabar, 1999, p31.

${ }^{5}$ See, for example, 'Editorial Policy', The Public Historian, vol 19, no 2, 1997, p152.

${ }^{6}$ David G.Vanderstel, 'The National Council on Public History', Public History Review, vol 10, 2003, p131.

${ }^{7}$ See Noel J. Stowe, 'Public History Curriculum: Illustrating Reflective Practice' and Shelly Bookspan, 'Something Ventured, Many Things Gained: Reflections on Being a Historian-Entrepreneur', The Public Historian, vol 28, no 1, 2006, respectively pp39-65; 67-74.

${ }^{8}$ Columbia University Press, New York, 1998. 
${ }^{9}$ Sheldon Hackney, 'The American Identity', The Public Historian, vol 19, no $1,1997, \mathrm{p} 22$.

${ }^{10}$ See, for example, Eric Foner, Who Owns History?: Rethinking the Past in a Changing World, Hill and Wang, New York, 2002, chapter 7, "Who is an American?'.

${ }^{11}$ David Thelen, 'A Participatory Historical Culture', http://chnm.gmu.edu/survey/afterdave.html nd, p2.

${ }_{12}$ ibid.

${ }^{13}$ Patricia Mooney-Melvin, 'Professional Historians and the Challenge of Redefinition', in James B. Gardner and Peter S. LaPaglia (eds), Public History: Essays form the Field, Krieger Publishing Company, Malabar, 1999, p9. Ian Tyrell has argued that the threat to history is a recurrent, exaggerated, and often misunderstood one and that history has adapted to and influenced its changing publics more than the profession is given credit for'. He concludes, however, with 'a mixed picture of continuity and change, of achievement and failure'. See Ian Tyrrell, Historians in Public: The Practice of American History, 1890-1970, The University of Chicago Press, Chicago, 2005, pp2; 254.

${ }^{14}$ op cit, p3.

${ }^{15}$ ibid, p11.

${ }^{16}$ ibid, p2.

${ }^{17}$ David Glassberg, Sense of History: The Place of the Past in American Life, Massachusetts Press, Amherst MA, 2001, p210.

${ }^{18}$ Hilda Kean, 'Personal and Public Histories: Issues in the presentation of the past', in Brian Graham and Peter Howard (eds), The Ashgate Research Companion to Heritage and Identity, Ashgate, Aldershot, 2008, pp53-62.

${ }^{19}$ Thelen, op cit, pp7-8.

${ }^{20}$ Ronald J. Grele, 'Whose Public? Whose History?: What is the Goal of a Public Historian?', The Public Historian, vol 3, no 1, 1981, pp44-6.

${ }^{21}$ Howard Green, 'A Critique of the Professional Public History Movement', Radical History Review, vol 25, no 28, 1981, pp164-71.

${ }^{22}$ Roy Rosenzweig, 'Everyone a Historian', http://chnm.gmu.edu/survey/afterroy.html, p11.

${ }^{23}$ ibid.

${ }^{24}$ op cit, p48.

${ }^{25}$ Susan Benson, Stephen Brier and Roy Rosenzweig (eds), Presenting the Past: Essays on History and the Public, Temple University Press, Philadelphia, 1986.

${ }^{26}$ Daniel Walkowitz, 'Series in Public History: “Around the Globe"', Radical History Review, vol 75, no 79, 1999.

${ }^{27}$ Daniel Walkowitz and Lisa Maya Knauer (eds), Memory and the Impact of Political Transformation in Public Space, Duke University Press, Durham, NC, 2004 and Daniel Walkowitz and Lisa Maya Knauer (eds), Memory, Race and Nation in Public Space, Duke University Press, Durham, NC, 2007.

${ }^{28}$ Ludmilla Jordanova, The Practice of History, Arnold, London, 2000, p155.

${ }^{29}$ Jeremy Black, Using History, Hodder Arnold, London, 2005, pix.

${ }^{30}$ Paul Ashton and Hilda Keane (eds), People and Their Pasts: Public History Today, Palgrave Macmillan, Basingstoke, 2009.

${ }^{31}$ Katherine Hodgken and Susannah Radstone, Contested Pasts: the politics of memory, Routledge, London, 2003, p3. 
${ }^{32}$ See Paula Hamilton and Linda Shopes, 'Introdution', in Paula Hamilton and Linda Shopes (eds), Oral History and Public Memories, Temple University Press, Philadelphia, 2008.

${ }^{33}$ David Glassberg, 'Public History and the Study of Memory', The Public Historian, vol 18 no 2, 1996, pp7-23.

${ }^{34}$ David Lowenthal, 'History and Memory', The Public Historian, vol 19, no2, 1997, p33. The roundtable respondents included Michael Frisch, Edward Linenthal, Michael Kannen, Linda Shopes, Jo Blatti, Robert Archibald and Barbara Franco. See The Public Historian, vol 19, no 2, 1997.

${ }^{35}$ Felipe Fernandez-Armesto, 'Epilogue: What is History Now?', in David Cannadine (ed), What is History Now?, Palgrave Macmillan, Houndsmill, 2002, pp158; 160.

${ }^{36}$ Paul Cartledge, 'What is Social History Now?', in ibid, p29.

${ }^{37}$ Jordanova, History in Practice, p141.

${ }^{38}$ See, for example, Ashton and Keane, op cit.

${ }^{39}$ Jill Liddington, 'What is Public History?: Publics and their Pasts, Meanings and Practices', Oral History, vol 30, no 1, 2002, p90.

${ }^{40}$ Paul Ashton and Christopher Keating, 'Commissioned History', in Graeme Davison, John Hirst and Stuart Macintyre (eds), The Oxford Companion to Australian History, Oxford University Press, Melbourne, 1998, p141.

${ }^{41}$ op cit.

${ }^{42}$ ibid, p92 (my emphasis).

${ }^{43}$ ibid, p91.

${ }^{44}$ See, for example, Michelle Arrow, '"I want to be a TV historian when I grow up": On Being a Rewind Historian', Public History Review, vol 12, 2006, p81.

${ }^{45}$ See Paul Ashton and Paula Hamilton, 'Introduction: the house of history' and 'The New Professionals: Public History', in Paul Ashton and Paula Hamilton, History at the Crossroads: Australians and the Past, Halstead Press, Sydney, 2010).

${ }^{46}$ Greg Denning, 'Some Beaches are Never Closed: Foundation and Future Reflections on the History Institute, Victoria', Rostrum, no 19, December 2001, p29 cited in Ruth Donovan, 'Australian Public History: Growth of a Profession?', PhD thesis, Department of History, University of Western Australia, 2007, p157.

${ }^{47}$ Jordanova, op cit, p155.

${ }^{48}$ Hilda Kean, 'Public History and Raphael Samuel: a forgotten radical pedagogy?', Public History Review, vol 11, 2004, p51.

${ }^{49}$ Raphael Samuel, 'Local history and oral history', History Workshop Journal, vol 1, no 1, 1976, pp191-208.

${ }^{50}$ Raphael Samuel, Theatres of Memory: Past and Present in Contemporary Culture, vol 1, Verso, London, 1994, px.

${ }^{51}$ ibid, p8.

${ }^{52}$ Kean, 'Public History and Raphael Samuel', p52.

${ }^{53}$ Hilda Kean, Paul Martin and Sally J. Morgan (eds), Seeing History: Public History in Britain Now, Francis Boutle, London, 2005, p13.

${ }^{54} \mathrm{ibid}, \mathrm{p} 15$.

${ }^{55}$ Bronwyn Dalley and Jock Phillips (eds), Going Public: The Changing Face of New Zealand History, Auckland University Press, Auckland, 2001, p9. 


\footnotetext{
${ }^{56}$ Graeme Davison, 'Public History', in Graeme Davison, John Hirst and Stuart Macintyre (eds), The Oxford Companion to Australian History, Oxford University Press, Melbourne, 1998, p532.

${ }^{57}$ See for example, Graeme Davison, The Use and Abuse of Australian History, Allen and Unwin, Sydney, 2000; John Rickard and Peter Spearritt (eds), Packaging the Past?: Public Histories, special issue of Australian Historical Studies, vol 24, no 96, 1991; and Paul Ashton and Paula Hamilton, 'Blood Money?: Race and Nation in Australian Public History', Radical History Review, no 76, 2000, pp188-207.

${ }^{58}$ See, for example, Paul Ashton and Paula Hamilton, 'Streetwise: Public History in New South Wales', Public History Review, vols 5/6, 1996-7, p15. ${ }^{59}$ op cit, pv.

60 'Public History', in Oxford Companion to Australian History, p532.

${ }^{61}$ Samuel, Theatres of Memory, p8.

${ }^{62}$ E.J. Hobsbawm and Terrence Ranger, The Invention of Tradition, Cambridge University Press, London, 1984, p263.

${ }^{63}$ Ashton and Hamilton, 'Streetwise', p16.

${ }^{64}$ Paula Hamilton and Paul Ashton (eds), Australians and the Past, special issue of Australian Cultural History, vol 22, 2003. See also Ashton and Hamilton, History at the Crossroads.

${ }^{65} \mathrm{M}$. Hughes-Warrington, History Goes to the Movies: Studying history on film, Routledge, Oxon, 2007, p32.
} 